\title{
Perancangan Aplikasi Pengenalan Kepramukaan Dengan Metode Waterfall Berbasis Android
}

\author{
Serlyn Febrianti ${ }^{1}$, Fitri Latifah ${ }^{2}$, Taufik Asra ${ }^{3}$ \\ ${ }^{1,2}$ STMIK Nusa Mandiri \\ e-mail: ${ }^{1}$ serlynfebrianti27@gmail.com, ${ }^{2}$ fitri.flr@ nusamandiri.ac.id \\ ${ }^{3}$ Universitas Bina Sarana Informatika \\ e-mail: ${ }^{3}$ taufik.tas@bsi.ac.id

\begin{tabular}{ccc}
\hline Diterima & Direvisi & Disetujui \\
$21-02-2020$ & $24-04-2020$ & $20-05-2020$ \\
\hline
\end{tabular}

\begin{abstract}
Abstrak - Pramuka salah satu Pendidikan non formal yang bertujuan untuk meningkatkan nilai etika, akhlak mulia, pengendalian diri serta potensi diri yang diterapkan dalam Undang-Undang Gerakan Pramuka No.12 Tahun 2010. Saat ini extrakulikuler kepramukaan sudah menjadi materi wajib disetiap seluruh sekolah dasar, menengah pertama maupun menengah atas. Dengan aplikasi android siswa dapat dengan mudah mempelajari materi kepramukaan dimanapun dan kapanpun, dengan aplikasi ini siswa lebih semangat untuk belajar karena disertai dengan vidio dan materi pembelajaran yang menarik, dan juga siswa tidak perlu membeli ataupun membawa buku saku pramuka. Metode penelitian yang digunakan terbagi menjadi beberapa tahap yaitu pengumpulan data, perancangan, pembuatan, dan tahap uji coba. Algoritma yang digunakan pada aplikasi ini ialah algoritma sequensial yang diterapkan pada senuah pencarian terstruktur. Aplikasi ini dibuat dengan Bahasa Java, Android Studio, dan ADT sebagai pluginnya, sedangkan SDK berfungsi sebagai development tools untuk aplikasi yang berbasis android. Dengan adanya aplikasi pengenalan kepramukaan berbasis android ini, maka bisa diambil kesimpulan bahwa metode pembelajaran dengan menggunakan alat bantu dapat meningkatkan minat siswa mengikuti kegiatan dan lebih mengenal kepramukaan.
\end{abstract}

Kata Kunci : Android, Pramuka, Algoritma Sequensial

\begin{abstract}
Scout one of the non-formal education aimed at improving the value of ethics, noble morality, selfcontrol, and the self-potential applied in the Scout Movement Act No. 12 the year 2010. Currently, Extrakulikuler Scout has become mandatory material in every whole school, first and middle secondary. With the Android app, students can easily learn scouting material wherever and whenever, with this application the students are more passionate to learn because it is accompanied by the interesting video and learning materials, and also students do not need to buy or carry a Scout pocketbook. The research methods used are divided into several phases, namely data collection, designing, manufacturing, and testing phase. The algorithm used in this application is a sequential algorithm that is applied to structured search corruption. The app is built with Java language, Android Studio, and ADT as Pluginnya, while the SDK serves as development tools for Android-based applications. With the introduction of this Android-based scout application, it can be concluded that learning methods using assistive devices can increase students 'interest in following activities and get to know the scout.
\end{abstract}

Keywords : Android, Scout, sequential algorithm

\section{PENDAHULUAN}

Pramuka salah satu Pendidikan non formal yang bertujuan untuk meningkatkan nilai etika, akhlak mulia, pengendalian diri serta potensi diri yang diterapkan dalam Undang-Undang Gerakan Pramuka No.12 Tahun 2010. Saat ini extrakulikuler kepramukaan sudah menjadi materi wajib disetiap seluruh sekolah dasar, menengah pertama maupun menengah atas. Tidak hanya itu, pentingnya Pendidikan non formal untuk mengasah kepribadian dalam kegiatan-kegiatan siswa yang bermanfaat khususnya pada Pramuka.

Untuk menjadi pramuka yang unggul dan berprestasi setiap siswa dibekali buku saku pramuka sebagai landasan pembelajaran dan pengingat dalam melaksanakan setiap kegiatan. Sering kali buku saku jarang digunakan, biasanya hanya diletakkan didalam tas ataupun disimpan.

Dengan perkembangan teknologi internet dan penggunaan smartphone yang semakin pesat di butuhkan aplikasi berbasis android guna menunjang 
kemudahan bagi siswa dalam mengetahui dan mencari informasi materi-materi kepramukaan. Dengan aplikasi android siswa dapat dengan mudah mempelajari materi kepramukaan dimanapun dan kapanpun, dengan aplikasi ini siswa lebih semangat untuk belajar karena disertai dengan vidio dan materi pembelajaran yang menarik, dan juga siswa tidak perlu membeli ataupun membawa buku saku pramuka.

\section{METODE PENELITIAN}

Penulis menggunakan 2 metode penelitian, yaitu Teknik Pengumpulan Data dan Metode Pengembangan Aplikasi.

Teknik Pengumpulan Data yang digunakan ialah Observasi yaitu dengan melihat dan melakukan langsung dari kegiatan yang dilakukan oleh sistem, dan Studi Pustaka yaitu pengumpulan informasi dengan cara membaca buku - buku sebagai referensi yang dijadikan acuan pada penulisan ini.

Metode Pengembangan Aplikasi yang digunakan penulis menggunakan model pengembangan sistem SDLC (System Development Life Cycle) metode Waterfall yang terdiri dari beberapa tahapan yaitu Analisa, Desain, Testing, Implementasi, dan Support.

\section{HASIL DAN PEMBAHASAN}

Algoritma yang digunakan pada aplikasi ini ialah algoritma sequensial yang diterapkan pada sebuah pencarian terstruktur.

Pada saat user memilih salah satu menu pada menu Home misalnya Pengetahuan Kepramukaan maka kemudian akan terbuka pencarian selanjutnya seperti GEPRA, UU, AD\&ART, dan SEJARAH jika user memilih salah satunya maka akan tampil pengetahuan informasi mengenai menu yang telah user pilih.

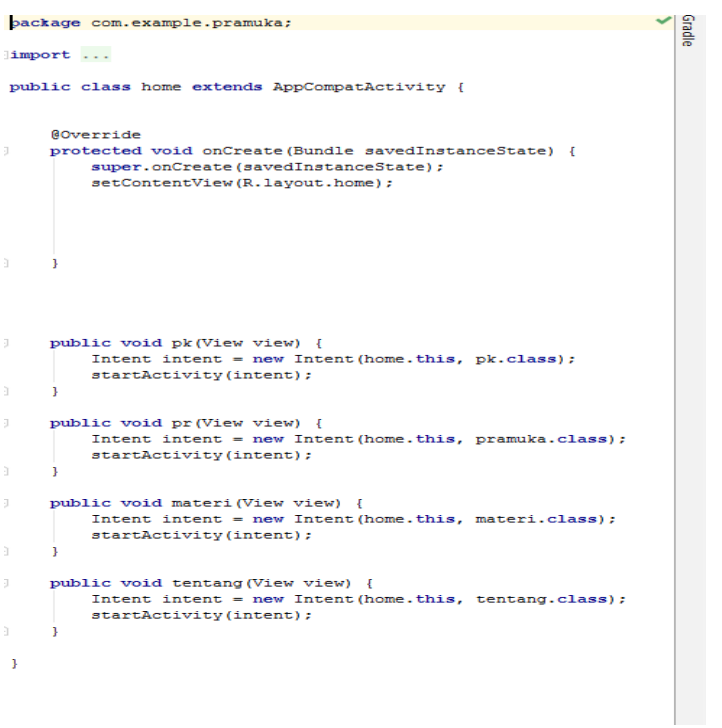

Gambar1. Algoritma Sequensial menu Home

Untuk Software Architecture digunakan UML untuk menggambarkan permodelan sistem, dan mendesain sistem perangkat lunak, khususnya pemrograman yang berorientasi objek.

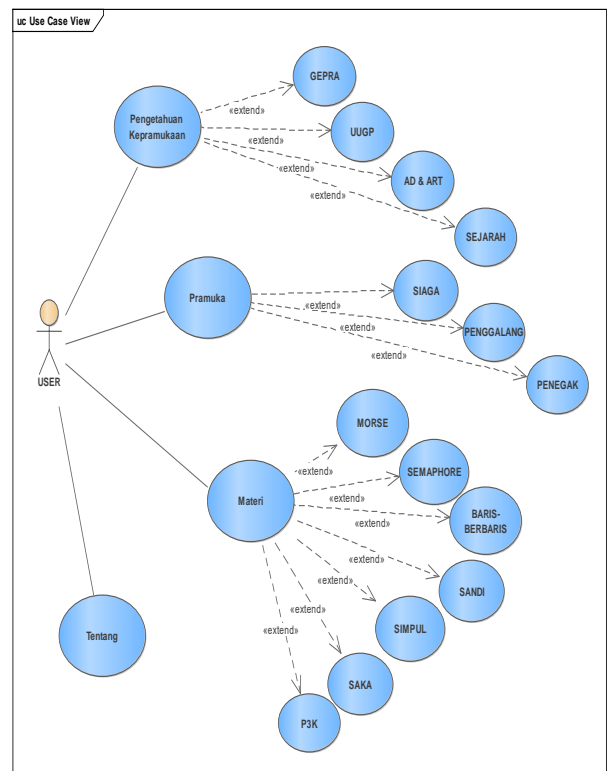

Sumber : Hasil Penelitian (2020)

Gambar2. Use Case Diagram

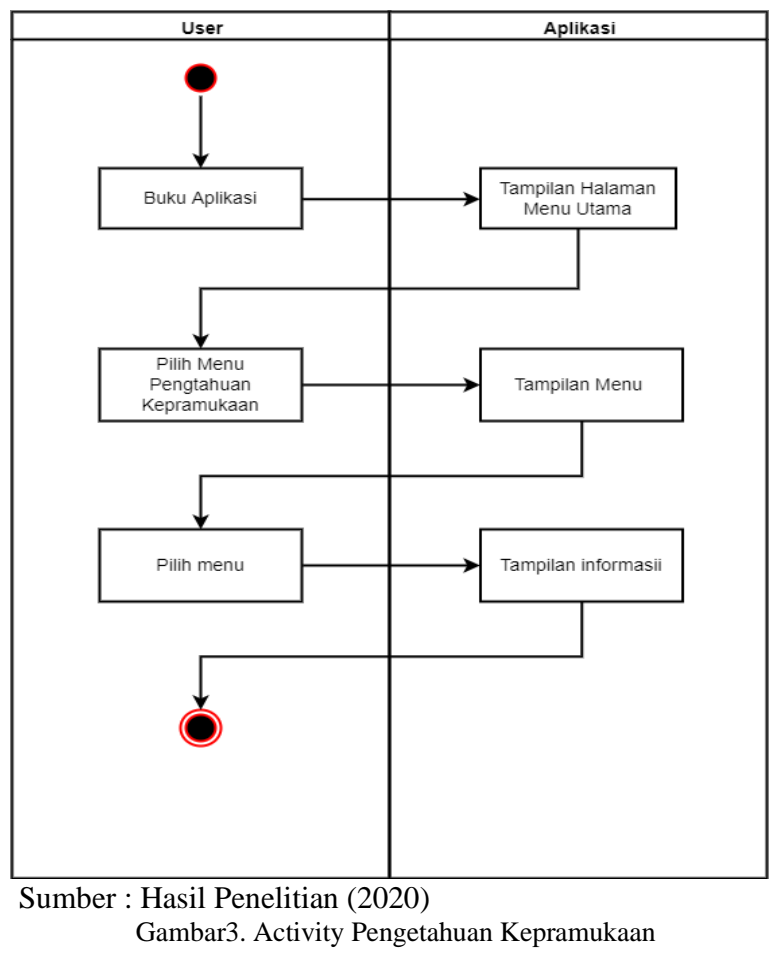

Sumber: Hasil Penelitian (2020) 


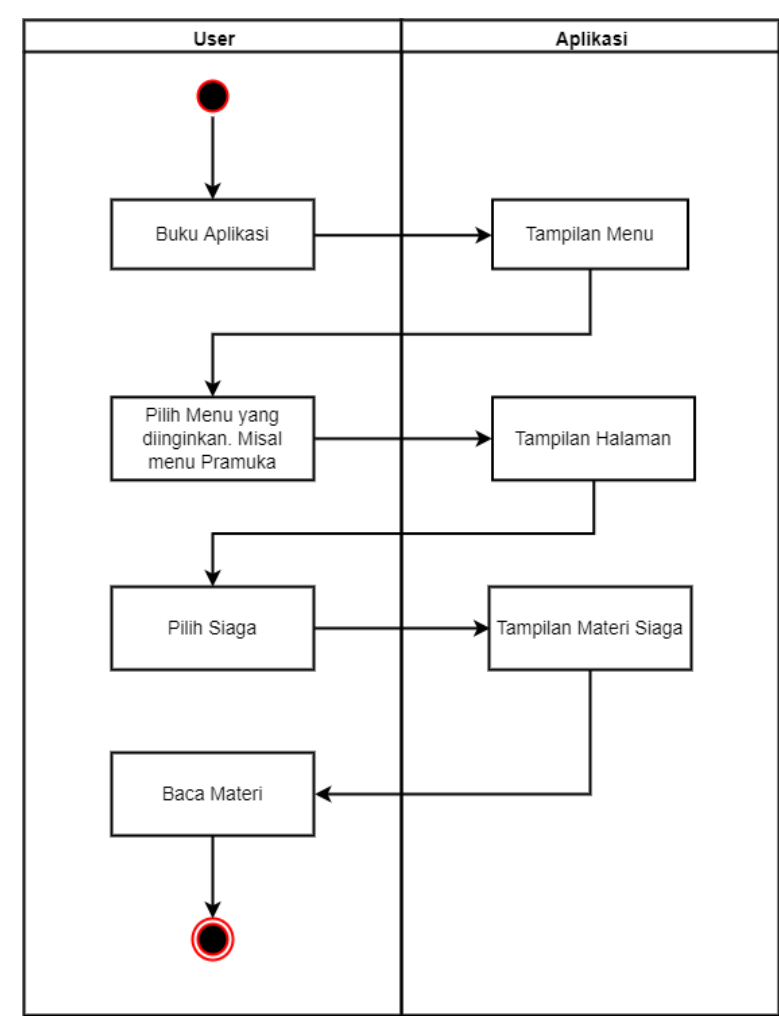

Sumber : Hasil Penelitian (2020)

Gambar4. Activity Pramuka

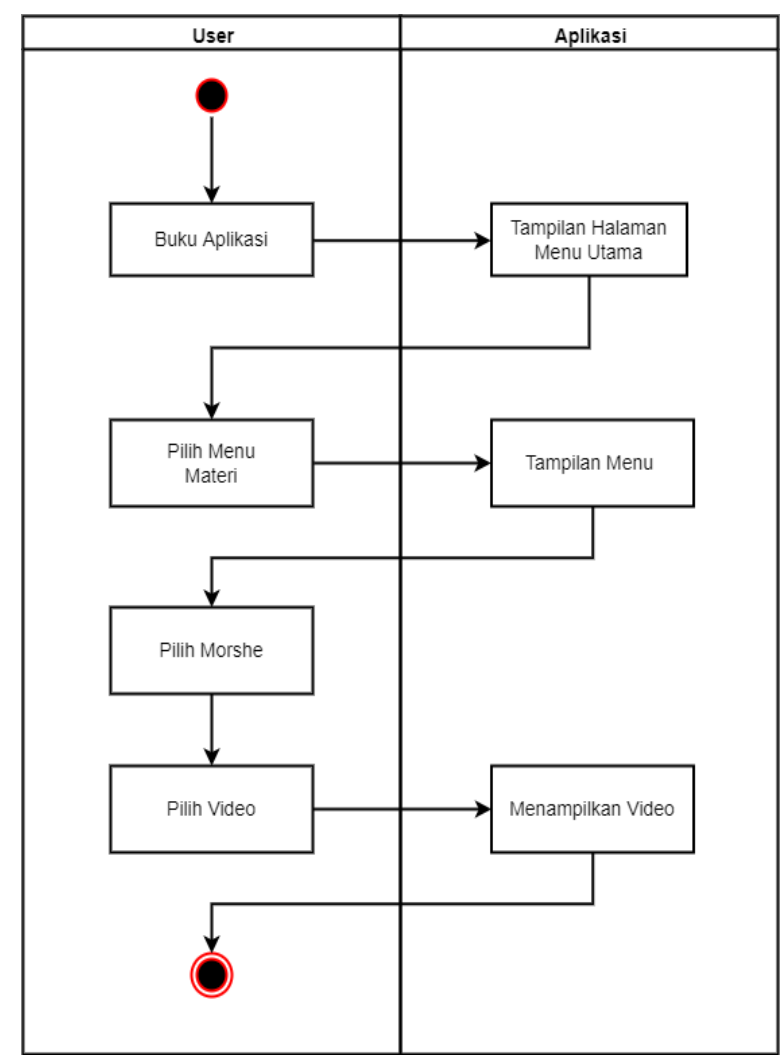

Sumber : Hasil Penelitian (2020)

Gambar5. Activity Materi

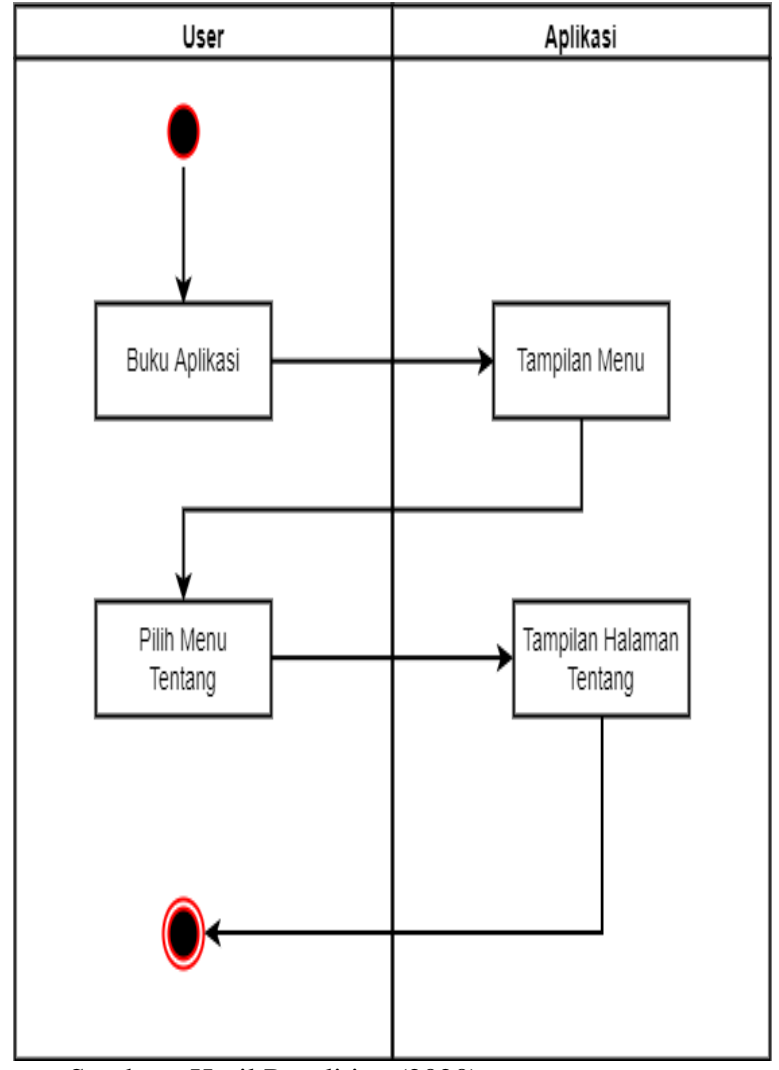

Sumber : Hasil Penelitian (2020)

Gambar6. Activity Tentang

Implementasi merupakan salah satu tahap dalam pengembangan sebuah perangkat lunak. Implementasi aplikasi pengenalan Pramuka pada aplikasi mobile android menggunakan bahasa pemrograman Java.

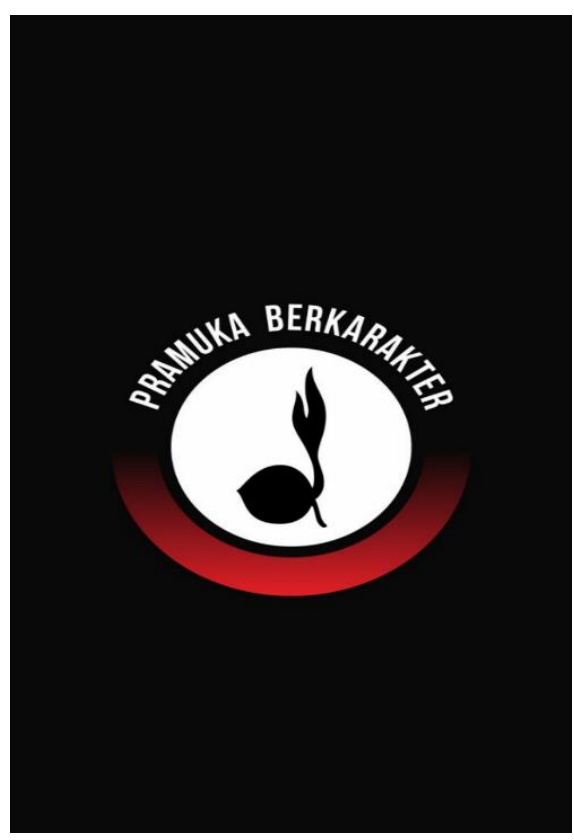

Sumber : Hasil Penelitian (2020) Gambar7. Splash Screen 


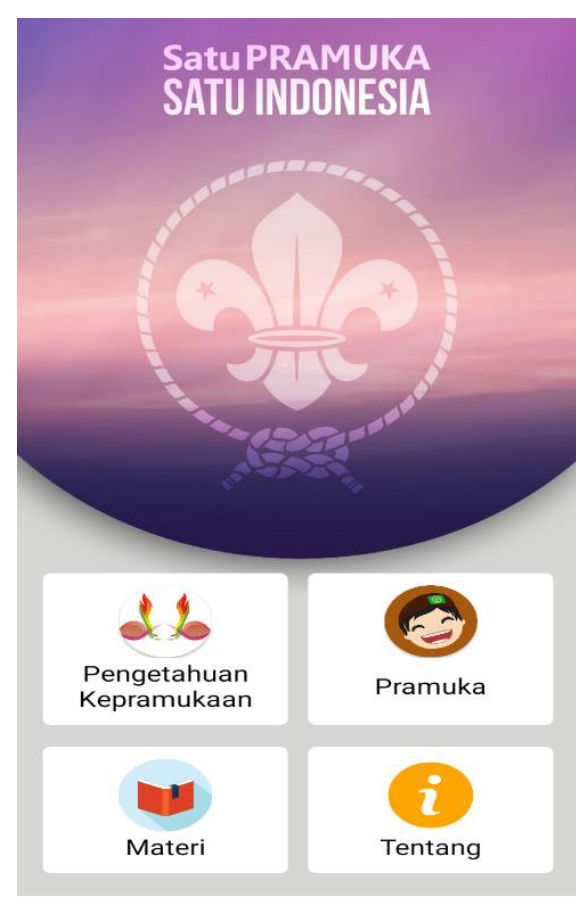

Sumber : Hasil Penelitian (2020) Gambar8. Home

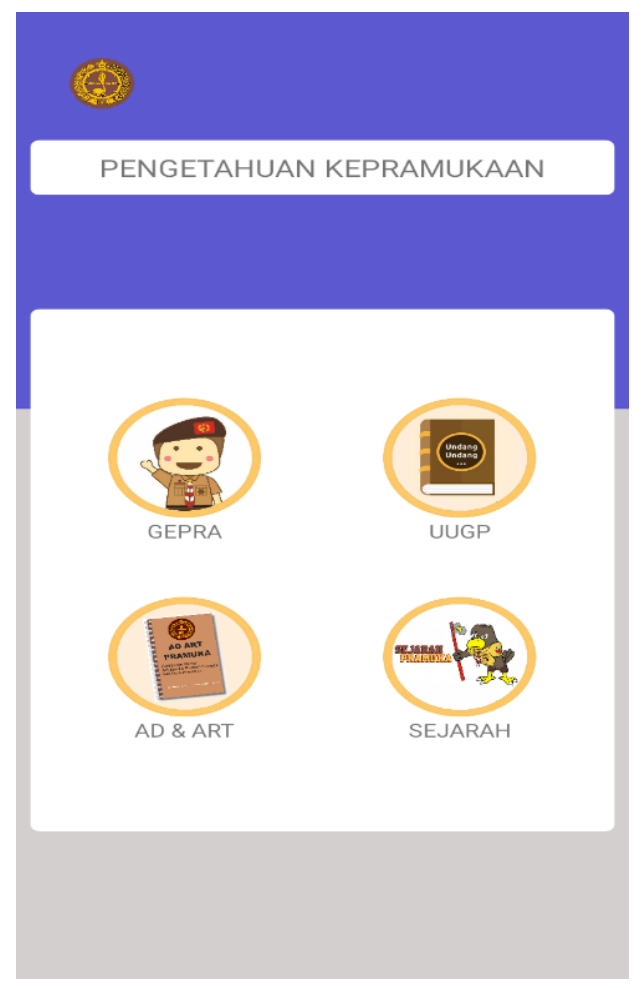

Sumber : Hasil Penelitian (2020)

Gambar9. Pengetahuan Kepramukaan

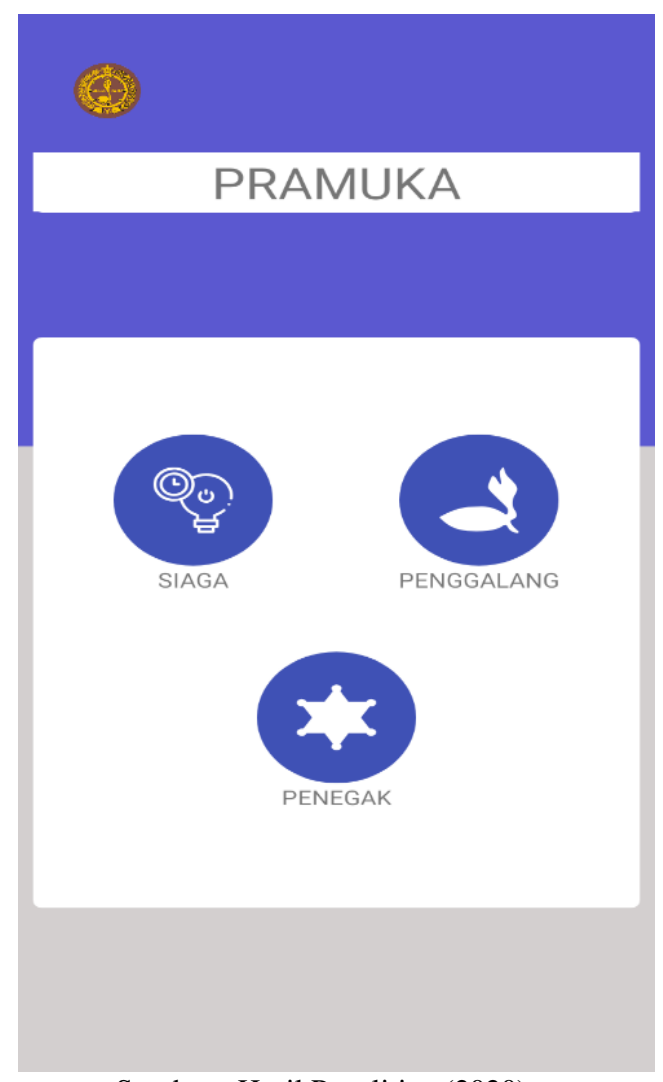

Sumber : Hasil Penelitian (2020) Gambar9. Pramuka

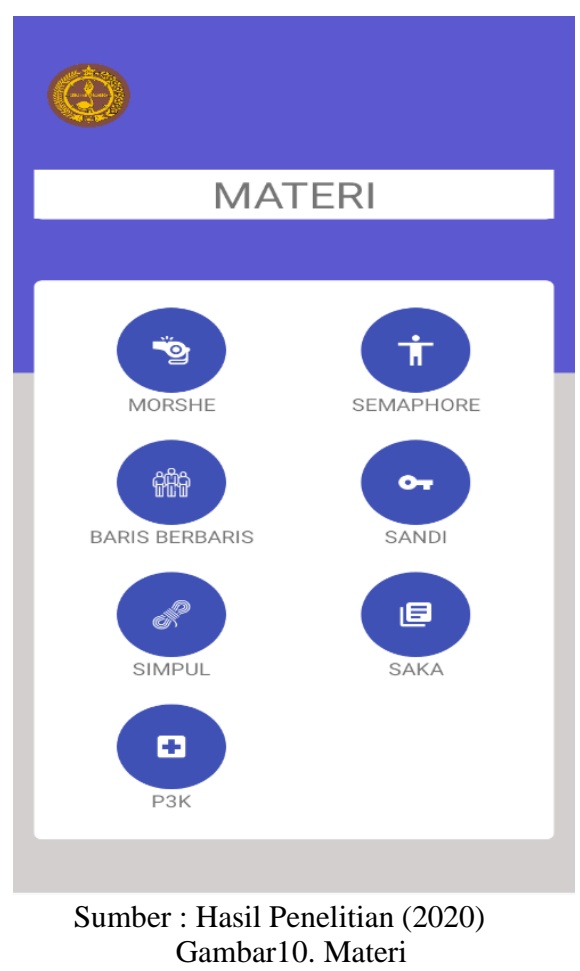



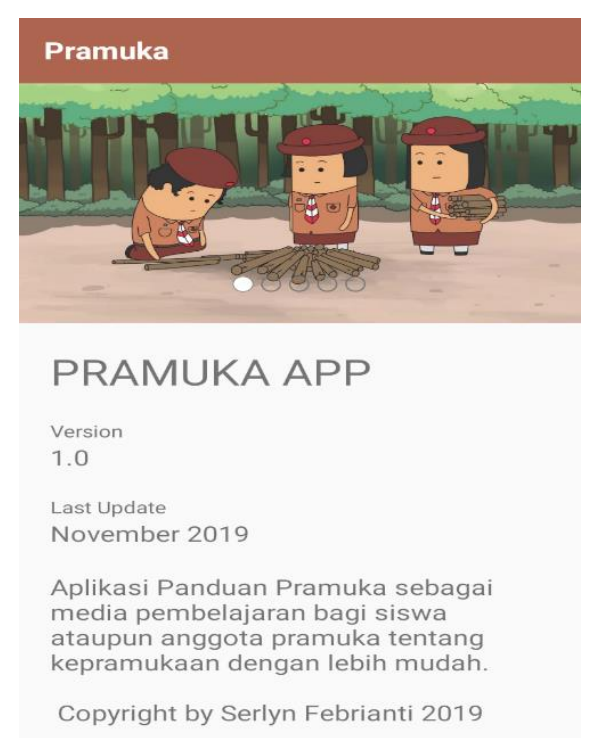

Sumber : Hasil Penelitian (2020) Gambar11. Tentang

Testing adalah proses pengujian suatu program untuk mendeteksi perbedaan antara kondisi yang ada dengan kondisi yang diinginkan (error atau bugs) untuk mengetahui kesiapan sebuah program dalam melakukan input data, proses pengolahan data dan output dari data yang diharapkan. Dalam aplikasi ini, pengujian yang digunakan adalah metode blackbox dan whitebox.

Whitebox testing adalah pengujian yang didasarkan pada pengecekan terhadap detail perancangan, menggunakan struktur kontrol dari desain program secara procedural untuk membagi pengujian ke dalam beberapa kasus pengujian.

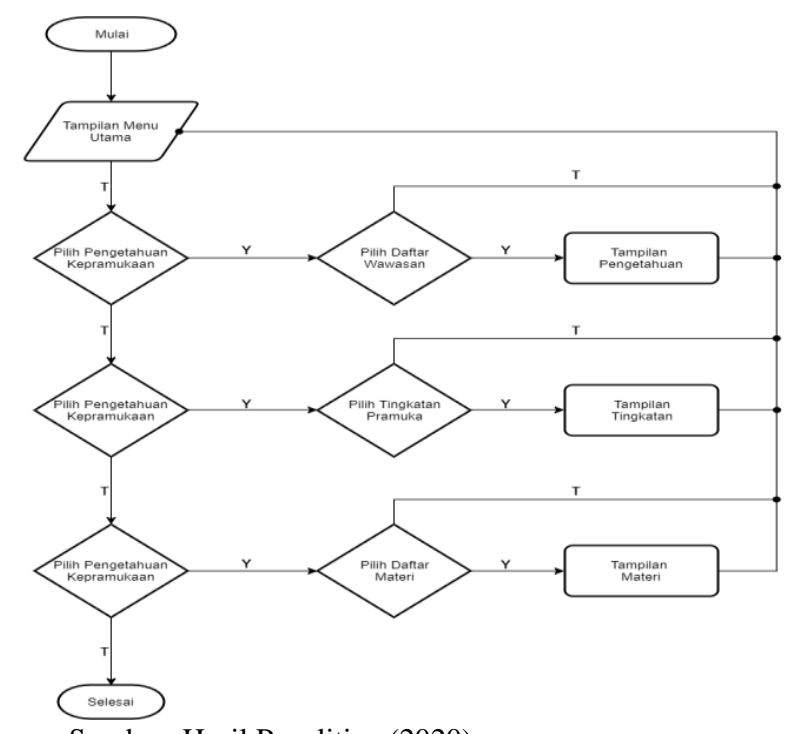

Sumber: Hasil Penelitian (2020)

Gambar12. Flowchart

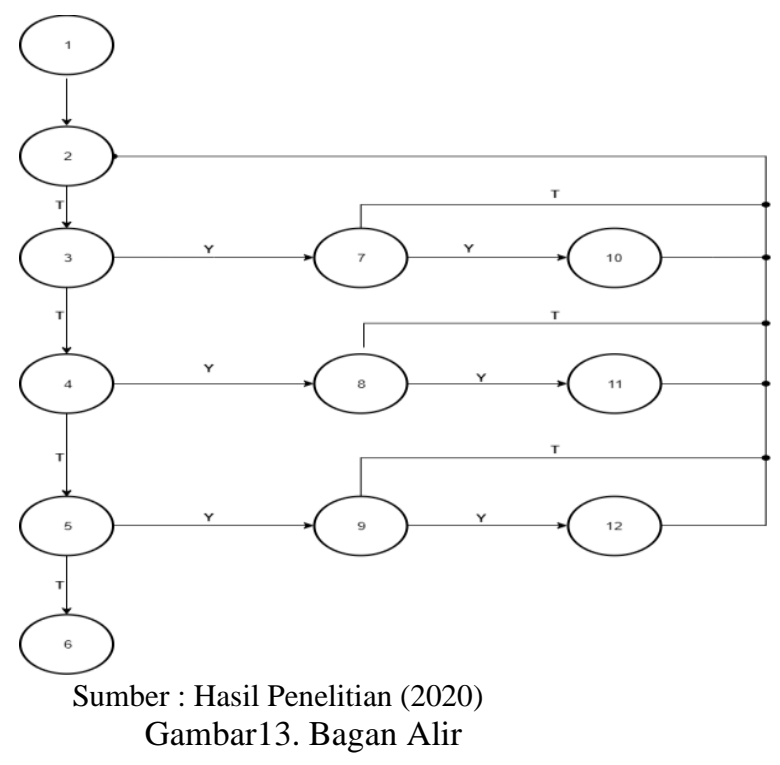

Berdasarkan Flowgraph diatas kemudian dapat dihitung kompleksitas siklomatisnya, ialah sebagai berikut :

$$
\begin{aligned}
\mathrm{V}(\mathrm{G}) & =(\mathrm{E}-\mathrm{N})+2 \\
& =(17-12)+2 \\
& =7
\end{aligned}
$$

Selanjutnya baris set yang dihasilkan dari jalur independennya adalah sebagai berikut :

$1-2-3-4-5-6$

$1-2-3-7-10-2-3-4-5-6$

$1-2-3-7-2-3-4-5-6$

$1-2-3-4-8-11-2-3-4-5-6$

$1-2-3-4-5-8-2-3-4-5-6$

$1-2-3-4-5-9-12-2-3-4-5-6$

1-2-3-4-5-9-2-3-4-5-6

Dari hasil perhitungan kompleksitas siklomatis sama dengan jumlah independent path dan jumlah region, maka dapat disimpulkan bahwa program memenuhi syarat.

\section{KESIMPULAN}

Metode pembelajaran dengan menggunakan alat bantu aplikasi berbasis android dapat meningkatkan minat siswa untuk mengikuti kegiatan dan lebih mengenal kepramukaan. Aplikasi pengenalan kepramukaan berbasis android dapat memudahkan siswa dalam memahami, mempelajari, dan mencari informasi dengan membuka satu aplikasi. Aplikasi yang dibuat penulis ini dibuat dengan Bahasa java, Android Studio, dan ADT sebagai pluginnya, sedangkan SDK berfungsi sebagai development tool untuk aplikasi yang berbasis android. Desain tampilan aplikasi dibuat dengan menggunakan adobe photoshop cc 2019. Aplikasi yang telah dibuat oleh penulis dapat membantu dalam pencarian materi, dan pengenalan wawasan Kepramukaan. Android merupakan penggabungan antara script JAVA dan XML. 


\section{REFERENSI.}

Ali, J. T. (2016). Perancangan Game Edukasi Android. 1(1), 1-8.

Andi Juansyah. (2015). Pembangunan Aplikasi Child Tracker Berbasis Assisted - Global Positioning System ( A-GPS ) Dengan Platform Android. Jurnal Ilmiah Komputer Dan Informatika (KOMPUTA), 1(1), 1-8. Retrieved from elib.unikom.ac.id/download.php?id=300375

Arifin, M., \& Hs, R. H. H. (2017). PERANCANGAN SISTEM INFORMASI PUSAT KARIR SEBAGAI UPAYA MENINGKATKAN RELEVANSI ANTARA LULUSAN DENGAN DUNIA KERJA MENGGUNAKAN UML Muhammad. ICTech, XII(2), 42-49.

Brucles, L. D., Kurniawan, R., \& Adrianto, S. (2017). Aplikasi Panduan Praktis Obat Herbal untuk Penyakit dalam Berbasis Platform Android. Informatika, 9(2), 40-46.

Cholifah, W. N., Yulianingsih, Y., \& Sagita, S. M. (2018). Pengujian Black Box Testing pada Aplikasi Action \& Strategy Berbasis Android dengan Teknologi Phonegap. STRING (Satuan Tulisan Riset Dan Inovasi Teknologi), 3(2), 206. https://doi.org/10.30998/string.v3i2.3048

Djafar, I. (2016). Perancangan Aplikasi Doa Dan Wirid. 6-7.

Haryati, S., Sudarsono, A., \& Suryana, E. (2015). Implementasi Data Mining Untuk Memprediksi Masa Studi Mahasiswa Menggunakan Algoritma C4.5 (Studi Kasus: Universitas Dehasen Bengkulu). Jurnal Media Infotama, 11(2), 130-138.

Hidayat, Aziz Setyawan, Wandy Ubleeuw, A. F. dan P. M. A. (2019). Sistem Pengolahan Data Nilai Berbasis Web Pada Sekolah Menengah Pertama. 5(2), 13-23.

Joko Sudrajad. (2010). Hubungan Nilai-nilai
Kepramukaan, karakter disiplin dan kerja keras terhadap prestasi belajar siswa mata pelajaran produktif di SMK PGRI 1 Ngawi. 110.

Asmi, A. R., Novemy, A., Surbakti, D., \& Hasan, Y. (2019). Pengembangan Model Mobile Learning Berbasis Aplikasi Android pada Mata Kuliah Sejarah ASEAN. Candrasangkala: Jurnal Pendidikan Dan Sejarah. 5(1), 30-40.

Mohidin, I., Mamase, S., \& Kai, A. (2019). Aplikasi Buku Saku Pramuka Berbasis Android. Jurnal Teknologi Informasi Indonesia (JTII), 1(1), 15. https://doi.org/10.30869/jtii.v1i1.292

Nuraini, R. (2015). Desain Algorithma Operasi Perkalian Matriks Menggunakan Metode Flowchart. Jurnal Teknik Komputer Amik Bsi, 1(1), $146 . \quad$ Retrieved from https://ejournal.bsi.ac.id/ejurnal/index.php/jtk /article/view/245

Purba, A. R., \& Ginting, G. L. (2018). Implementasi Algoritma String Matching pada Pencarian Arti Istilah-Istilah Pramuka Berbasis Mobile. Pelita Informatika Budi Darma, 17(April), 128-132.

Putra, D. W. T., \& Andriani, R. (2019). Unified Modelling Language (UML) dalam Perancangan SistemInformasi Permohonan Pembayaran Restitusi SPPD. Jurnal TEKNOIF (Teknik Informatika), 7(1), 32-39.

Rizal, M., \& Latifah, F. (2017). Perancangan Aplikasi Lokasi Wisata Kota Jakarta Menggunakan Algoritma Sequential Search Berbasis Android. In None (Vol. 13).

Widyaningsih, P., \& Indah, R. P. (2017). APLIKASI BUKU DIGITAL ATRAKTIF UNTUK MENDUKUNG PEMBELAJARAN BERBASIS FUN LEARNING MANAGEMENT DENGAN PENDEKATAN USER CENTERED DESIGN ( STUDI KASUS : MATAKULIAH ALGORITMA ). 7(2), 59-64. 